\title{
The Amphibians of the Mitaraka massif, French Guiana
}

\author{
Antoine FOUQUET \\ Laboratoire Évolution et Diversité biologique (EDB), UMR5174, \\ Bâtiment 4R1, 118 route de Narbonne, F-31077 Toulouse (France). \\ and Laboratoire Écologie, Évolution, Interactions des Systèmes amazoniens (LEEISA) \\ USR3456, Cayenne (French Guiana) \\ fouquet.antoine@gmail.com (corresponding author)
}

Nicolas VIDAL

Institut de Systématique, Évolution, Biodiversité (ISYEB), Muséum national d'Histoire naturelle, CNRS, Sorbonne Université, EPHE, Université des Antilles case postale 53, 57 rue Cuvier, F-75231 Paris cedex 05 (France)

Maël DEWYNTER

Fondation Biotope pour la biodiversité, 30 Domaine de Montabo, F-97300 Cayenne (French Guiana)

Submitted on 26 June 2018 | Accepted on 28 January 2019 | Published on 10 September 2019

KEY WORDS

Anura,

community,

diversity,

Gymnophiona,

Guiana Shield.

urn:Isid:zoobank.org:pub:9BD3D52A-809C-4373-B313-36723735B794

Fouquet A., Vidal N. \& Dewynter M. 2019. - The Amphibians of the Mitaraka massif, French Guiana, in Touroult J. (ed.), "Our Planet Reviewed" 2015 large-scale biotic survey in Mitaraka, French Guiana. Zoosystema 41 (19): 359-374. https://doi.org/10.5252/zoosystema2019v41a19. http://zoosystema.com/41/19

\section{ABSTRACT}

We undertook a 15-day survey of the amphibian fauna of the Mitaraka massif in southwestern French Guiana during the rainy season. We detected 56 species ( 12 species detected for the first time), including six only thanks to their calls. Thirteen additional species were previously detected from nearby sites. The total number of species occurring in the area is at least 69 but most of the species associated with temporary ponds remained undetected. Therefore, we assume the amphibian community of the Mitaraka massif could reach at least 75 species, which represents one of the richest amphibian faunas of the Guiana Shield. With at least six species not occurring further north in French Guiana, the amphibian fauna of the Mitaraka massif is notably distinct from the rest of the territory. Seven of the species discovered during the survey are highlighted here either because these new records represent range extensions or because they are putative new species. 


\begin{abstract}
RÉSUMÉ
Les Amphibiens du massif du Mitaraka, Guyane.

Nous avons réalisé un inventaire des amphibiens du massif du Mitaraka au sud-ouest de la Guyane durant 15 jours pendant la saison des pluies. Nous avons détecté 56 espèces (12 espèces étaient inconnues de la zone) dont six ne l'ont été que grâce à l'identification acoustique. Treize autres espèces ont été précédemment détectées lors d'inventaires réalisés dans des localités proches. Cela porte le nombre total d'espèces connues dans la région à 69 mais la plupart des espèces dont la reproduction est associée aux mares temporaires n'ont pas été détectées lors des inventaires. Par conséquent, nous supposons que la liste des amphibiens de la région est susceptible d'atteindre 75 espèces, ce qui représente une des plus riches communautés du plateau des Guyanes. Avec au moins six espèces qui sont inconnues plus au nord en Guyane, la faune de cette région apparaît distincte. Nous détaillons la présence de sept espèces, soit parce qu'elles représentent des extensions d'aire de distribution connue, soit parce qu'elles correspondent à des espèces potentiellement nouvelles.
\end{abstract}

MOTS CLÉS

Anoures,

diversité,

gymnophione

plateau des Guyanes.

\section{INTRODUCTION}

The lowlands of Guiana Shield (GS) harbour mostly forested ecosystems $(<600 \mathrm{~m})$ forming a hilly landscape peppered with inselbergs and relatively small rivers. These forests are amongst the most extensive and pristine of the world (Hammond 2005). Five different countries i.e., Brazil, Venezuela, French Guiana, Suriname, and Guyana host these forests that form a «bioregion » bounded by the Rio Branco, the Rupununi savanna and the Pantepuis on the West and the Negro/ Amazonas rivers on the South (Naka et al. 2012).

The amphibians found in that region have strong affinities with the rest of the adjacent parts of Amazonia, but also display a high degree of endemism (Duellman 1999). However, both the number of species and the degree of endemism of the fauna inhabiting these forests seem to be largely underestimated (Fouquet et al. 2007b, 2015a, 2016). In French Guiana alone, the number of anuran species known to occur rose from 103 in 2000 (Lescure \& Marty 2000) to 131 species in 2017 (IUCN France et al. 2017). Moreover, most DNAbased studies undertaken at the scale of Amazonia reveal that populations of the GS lowlands form endemic clades that most likely correspond to endemic species (e.g. Fouquet et al. 2015a, 2016; Caminer et al. 2017).

Some of these studies also suggest that a strong structure exists both in the communities (i.e., with distribution boundaries) and in the intraspecific genetic variation within the GS lowlands (Fouquet et al. 2012). In particular, there is a strong apparent heterogeneity between the coastal part and the southern part of French Guiana, both in terms of species composition and in the genetic structure of the species distributed throughout the area (Fouquet et al. 2012; Vacher et al. 2017). However, the inner part of the GS, such as the southern part of French Guiana and Suriname, is very difficult to access and, thus, the understanding of the community composition and of the distribution boundaries of the different species remain vague (Fouquet et al. 2015b).

In February-March 2015, a large-scale biodiversity survey ("Our planet revisited" expedition) was organized by the $\mathrm{Mu}$ séum national d'Histoire naturelle (MNHN) and Pro-Natura International within the Mitaraka Massif (Fig. 1). This remote area in the southwestern part of French Guiana is located within the core of the "Parc Amazonien de Guyane" National Park.

Very few data on the herpetofauna of the area have been collected so far. In a $100 \mathrm{~km}$ radius, only four localities in French Guiana (Blanc 2016; Gaucher \& de Massary 2005a, b; Dewynter \& Chaline 2016), and one in Amapá - Brazil (Dias Lima 2008) have been surveyed (Fig. 1). We herein present the results of our field amphibian survey of the Mitaraka Massif with an annotated checklist of the detected species and compared it with results from surrounding surveys.

\section{MATERIAL AND METHODS}

The survey lasted 15 days (23.II.-11.III.2015) and was undertaken during the rainy season by three herpetologists. The study area covered a $3 \mathrm{~km}$ radius centred on the camp Alama $\left(2.23577^{\circ} \mathrm{N}, 54.44928^{\circ} \mathrm{W}\right)$. However, most of the data were collected in a more focused area around the camp, i.e., along the trails opened for the survey. Only a few data were collected further than the $3 \mathrm{~km}$ radius, notably on nearby inselbergs that were searched for a few species associated to these particular habitats.

The amphibians were inventoried according to the Visual Encounter Survey (VES) and Acoustic Encounter Survey (AES) methods during mornings, afternoons and nights (c. 30 people*days total) in different habitats (river/stream banks, leaf litter, flooded areas). All amphibian species detected either by sight or hearing, whatever their distance from the observers, were taken into account in the inventory.

Calling males were recorded (records of 11 species have been deposited on the MNHN Soundlibrary http://sonotheque. mnhn.fr) and both sexes of each detected species were collected when possible. Specimens were photographed alive, euthanized using xylocaine $2 \%$, labelled, and then fixed using formalin after a piece of tissue was sampled and stored in $95 \%$ ethanol. Specimens were later transferred to $70 \%$ ethanol for permanent storage. Each specimen has been attributed a unique field number, i.e., AFXXX. The collected material is stored in the CNRS collection in Cayenne and will be partly deposited at the MNHN according to the agreement signed 


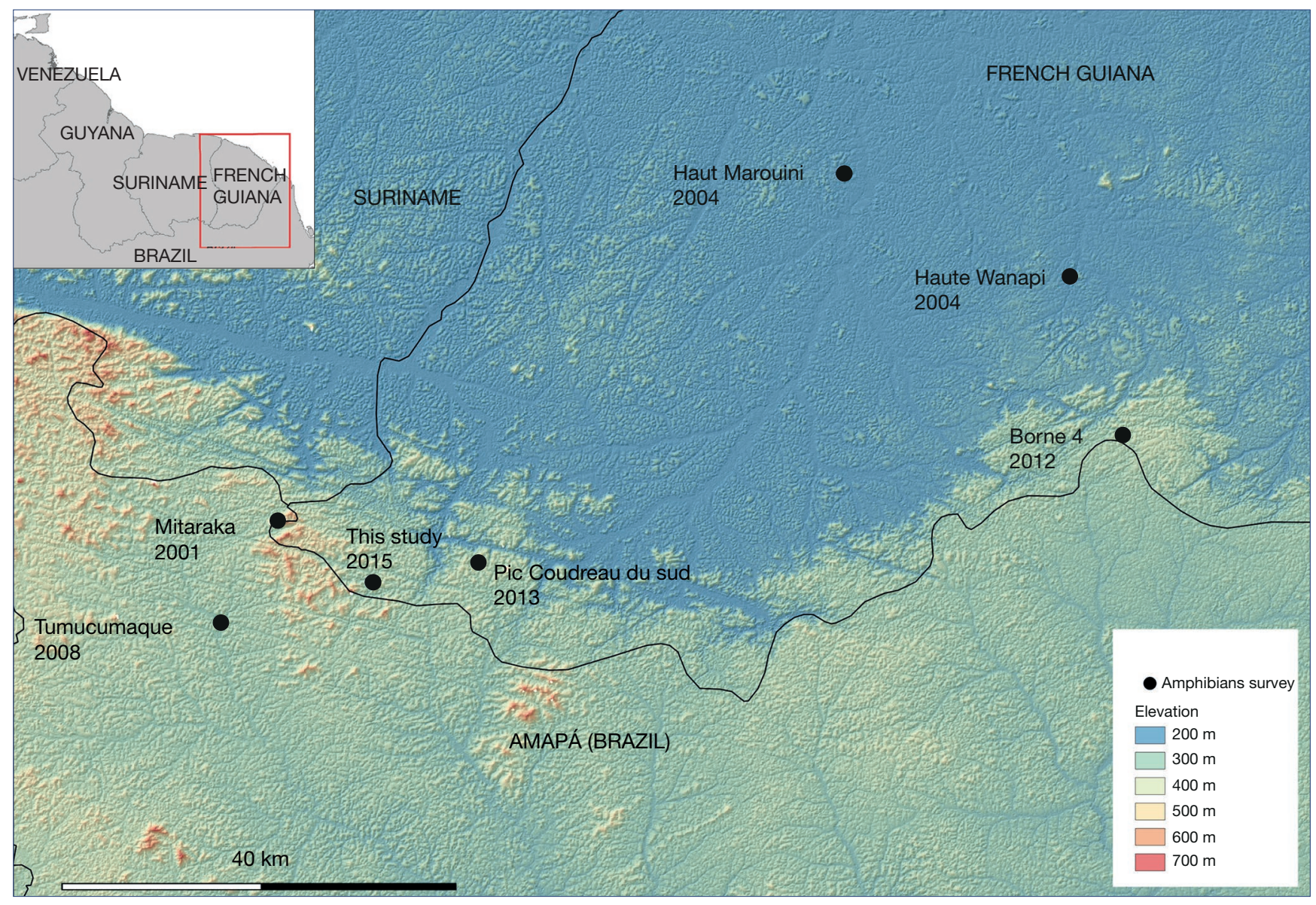

FIG. 1. - Topographic map showing the localities of the present survey and of the previous ones that have been undertaken in a $100 \mathrm{~km}$ radius.

among participating teams (ABS agreement detailed by Touroult et al. 2018). The specimens deposited in the MNHN are located in the "Reptiles \& Amphibians" collections and can be traced with their inventory numbers, MNHN-RA2015-XX, at the following address, https://science.mnhn.fr/ institution/mnhn/collection/ra/search.

The taxonomy follows Frost (2018). However, undescribed species known to be related to a nominal taxon were identified with a "aff." and "cf." when this identification or the relationship with this nominal taxon remained tentative. By doing so, we facilitate the taxonomic discussion.

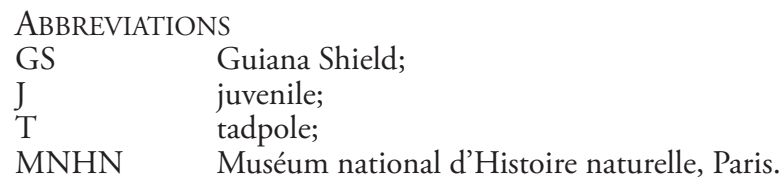

\section{RESULTS}

We detected 56 species of amphibians including one Gymnophiona Müller, 1832 (Table 1). We collected 151 specimens belonging to 50 species. Six arboreal species (Hyalinobatrachium mondolfii Señaris \& Ayarzagüena, 2001, Cochranella geijskesi (Goin, 1966), Pristimantis aff. zimmermanae (Heyer \& Hardy,
1991), Boana boans (Linnaeus, 1758), Trachycephalus hadroceps (Duellman \& Hoogmoed, 1992), Trachycephalus resinifictrix (Goeldi, 1907)) were only acoustically detected and not collected. This survey represents one of the richest amphibian fauna documented from the GS so far. Considering the other surveys undertaken in a $100 \mathrm{~km}$ radius, "Borne 4" in French Guiana (Fig. 1) is the second richest amphibian fauna with 42 amphibian species. In total, 12 additional species of amphibians (11 Anura and one Gymnophiona) were found in these surveys. Conversely, our survey recovered 12 species that were not collected in previous surveys. Hylidae Rafinesque, 1815 and Leptodactylidae Werner, 1896 are the most represented families with 12 and 10 species respectively.

\section{CATALOGUE}

Family ALLOPHRYNIDAE Savage, 1973

\section{Allophryne ruthveni Gaige, 1926}

TYPE LOCALITY. — Guyana, Tukeit Hill, below Kaiteur Falls. Distribution. - Widespread in Amazonian lowlands.

TAXONOMIC REMARKS. - The populations from French Guiana unambiguously belong to the nominal species. 
Habitat in Mitaraka. - Specimens were encountered calling from low height in the trees along flooded areas of the Alama creek after heavy rainfall.

MATERIAL EXAMINED. — La Planète Revisitée Guyane 2015, MNHNPNI, APA973-1: AF2766; AF2779.

\section{Family BUFONIDAE Gray, 1825}

\section{Amazophrynella teko}

Rojas, Fouquet, Ron, Hernández-Ruz, Melo-Sampaio, Chaparro, Vogt, de Carvalho, Pinheiro, Ávila, Farias, Gordo \& Hrbek, 2018

Type LOCALITY. — French Guiana, Alikéné.

DisTRIBUTION. - Lowlands of the eastern part of the Guiana Shield (Suriname, French Guiana, Brazil Amapá).

TAXONOMIC REMARKS. - Seven paratypes (four males and three females) of this recently described species were collected in Mitaraka during this survey, thus the specimens encountered unambiguously belong to this species.

HabitaT In MitaraKa. - Many specimens were encountered during the day as well as at night. Some males were calling at dusk along the swampy stream beds.

Material EXAMINED. — La Planète Revisitée Guyane 2015, MNHNPNI, APA973-1: AF2722 (MNHN-RA-2015-138 ơ); AF2723 ( ơ); AF2729 (MNHN-RA-2015-137 ơ); AF2730 (MNHNRA-2015-141 ᄋ); AF2735 (MNHN-RA-2015-143 ㅇ); AF2758 (MNHN-RA-2015-139 ơ); AF2810 (MNHN-RA-2015-140 07); AF2811 (MNHN-RA-2015-142 ९).

MALE CALL. - MNHN-SO-2019-18 (AF2758, MNHNRA-2015-139)

\section{Rhaebo guttatus (Schneider, 1799)}

TyPE LOCALITY. - Suriname (without precision).

Distribution. - Widespread in Amazonia.

TAXONOMIC REMARKS. - The populations from French Guiana unambiguously belong to the nominal species.

HABITAT IN MitARAKA. - It was conspicuously calling and found along the rivers.

Material EXAMINed. — La Planète Revisitée Guyane 2015, MNHNPNI, APA973-1: AF2803 (no specimen, Toe clip).

\section{Rhinella lescurei}

Fouquet, Gaucher, Blanc \& Vélez-Rodriguez, 2007

TyPe LOCALITY. — French Guiana, Haute Wanapi.

Distribution. - This species is known to occur in Suriname and French Guiana and probably occurs in adjacent Brazil.

TAXONOMIC REMARKS. - The Mitaraka massif is close to the type locality, thus the specimens encountered unambiguously belong to the nominal species.
Habitat in MitaraKa. - It was found calling at dusk, perched on small branches nearby creeks.

Material eXamined. — La Planète Revisitée Guyane 2015, MNHNPNI, APA973-1: AF2733; AF2741; AF2753.

\section{Rhinella martyi}

Fouquet, Gaucher, Blanc \& Vélez-Rodriguez, 2007

TYPE LOCALITY. - Brownsberg Nature Park, Suriname.

Distribution. - From Guyana to Brazil Amapá, but only in the southwestern part of French Guiana.

TAXONOMIC REMARKS. - Closely related and difficult to differentiate from Rhinella cf. margaritifera Laurenti, 1768 (occurring in the rest of French Guiana). This species only occupies the southwestern part of French Guiana.

HABITAT IN MitARAKA. - It breeds in flooded parts of slow flowing streams but was found wandering on the forest litter throughout the area.

Material examined. - La Planète Revisitée Guyane 2015, MNHN-PNI, APA973-1: AF2771 (o'); AF2805 (广); AF2852 (\%); AF2867 (\%).

\section{Family Centrolenidae Taylor, 1951}

Cochranella geijskesi (Goin, 1966)

TyPe LOCALITY. — Suriname, Wilhelmina Mountains.

DisTRIBUTION. - This species is known only from its type locality but we assume that it occurs at least throughout the eastern Guiana Shield based on call identification.

TAXONOMIC REMARKS. - Specimens identified as Cochranella gei$j$ skesi were collected and recorded in French Guiana. This call was encountered in Sipaliwini, Suriname (Fouquet et al. 2015b) and in many areas of French Guiana.

HABITAT In MitARAKA. — This centrolenid was conspicuously calling from the canopy above the creeks but was not collected.

Material eXAmined. - No record.

\section{Hyalinobatrachium cappellei}

(Van Lidth de Jeude, 1904)

Type LOCALITY. — Suriname, Saramacca River.

Distribution. - Widespread in Amazonia.

TAXONOMIC REMARKS. - The populations from French Guiana unambiguously belong to the nominal species.

Habitat In MitaraKa. — Many individuals were heard calling on water-overhanging leaves along streams.

Material eXAmined. — La Planète Revisitée Guyane 2015, MNHNPNI, APA973-1: AF2761 (ơ). 
A

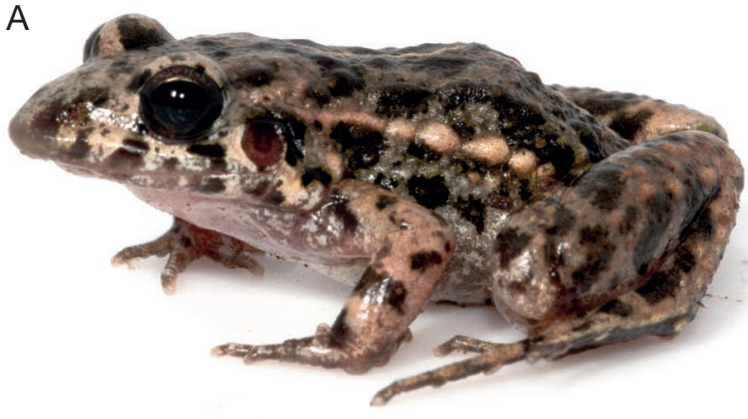

C

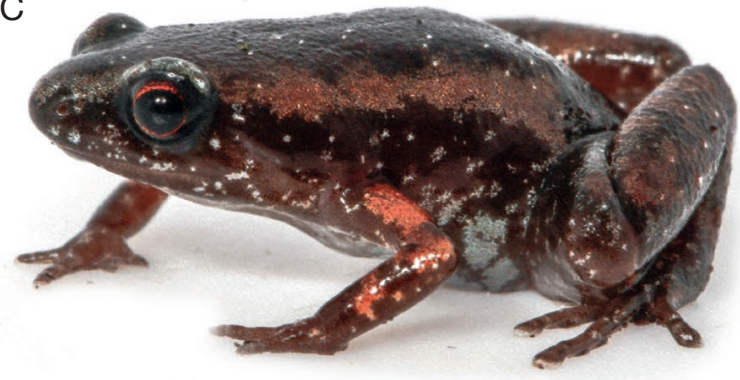

$\mathrm{E}$
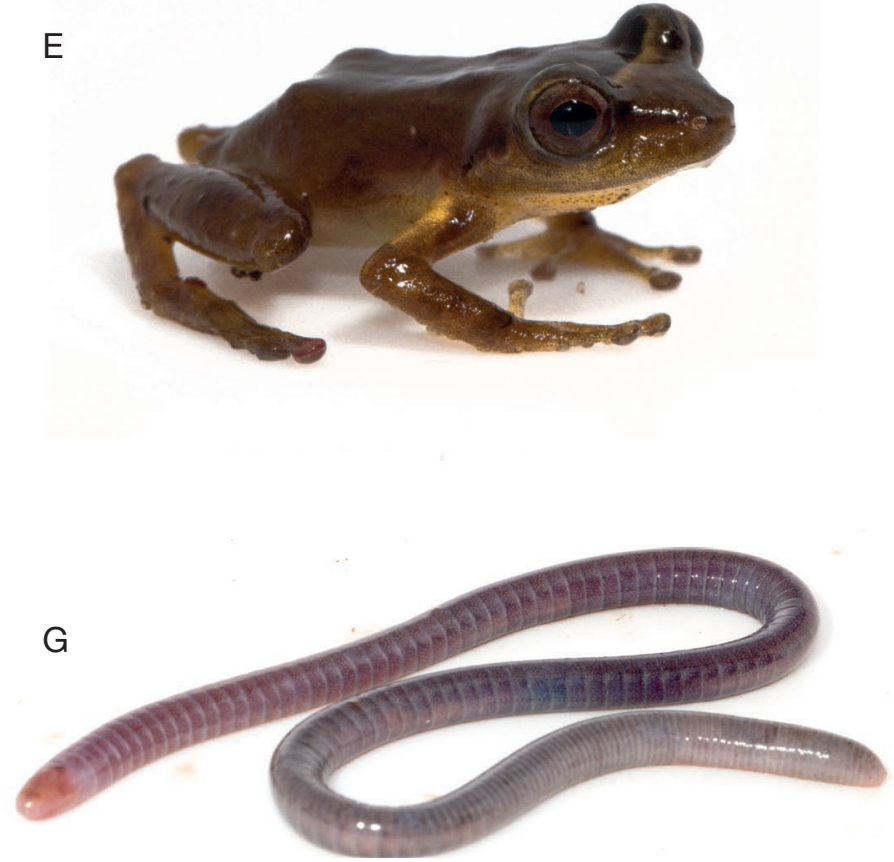

B
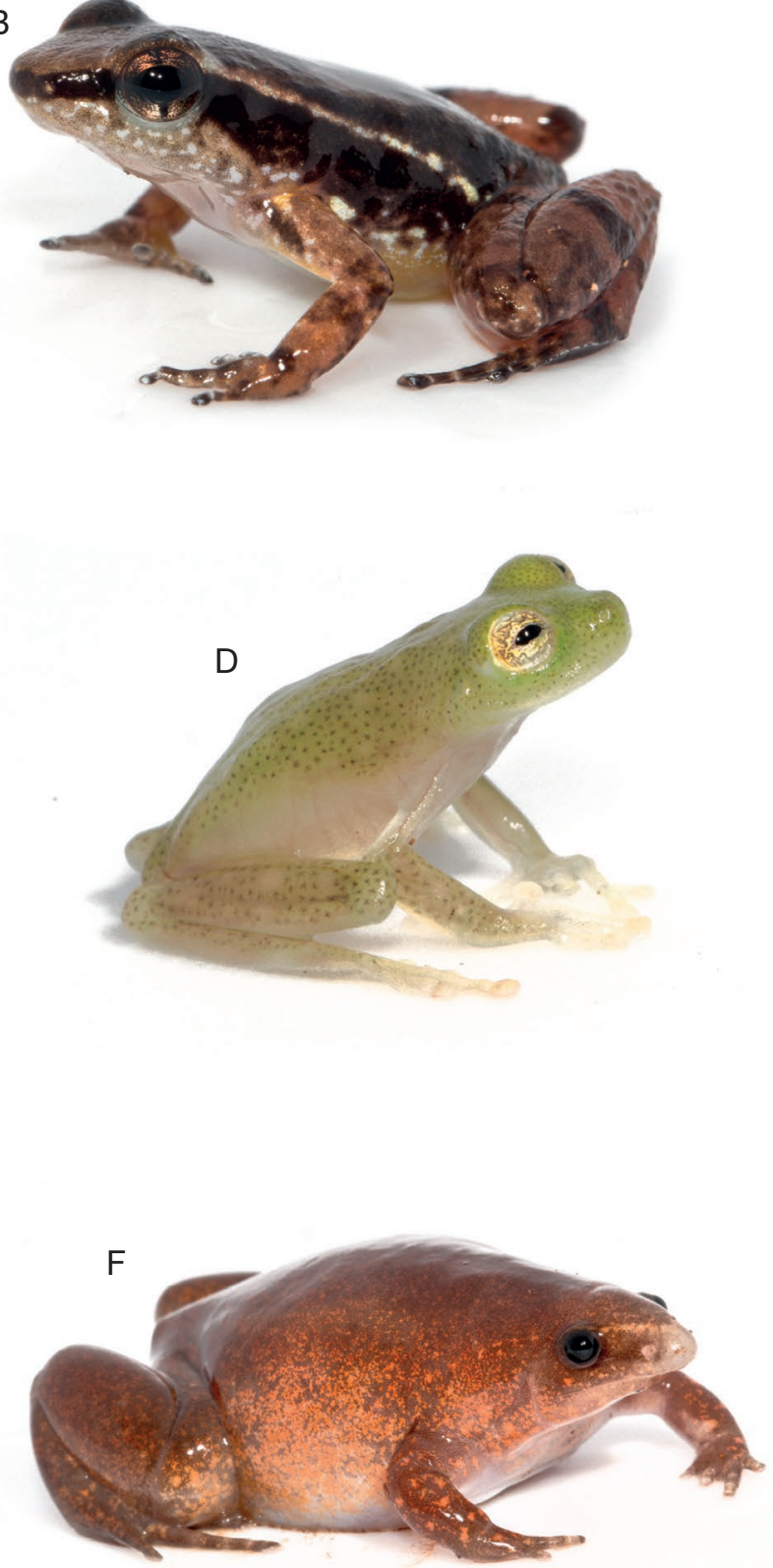

FIG. 2. - Seven remarkable species found during the survey: A, Adenomera hylaedactyla (Cope, 1868); B, Anomaloglossus mitaraka Fouquet, Vacher, Courtois, Deschamps, Ouboter, Jairam, Gaucher, Dubois \& Kok, 2019; C, Chiasmocleis aff. haddadi Peloso, Sturaro, Forlani, Gaucher, Motta \& Wheeler, 2014; D, Hyalinobatrachium kawense Castroviejo-Fisher, Vilà, Ayarzagüena, Blanc \& Ernst, 2011; E, Pristimantis aff. pluvialis Shepack, von May, Ttito \& Catenazzi, 2016; F, Synapturanus cf. mirandaribeiroi Nelson \& Lescure, 1975; G, Microcaecilia cf. rochai Maciel \& Hoogmoed, 2011. 
TABLE 1. - List of the species detected in the present survey (with number of specimens collected) and in nearby previous surveys. Symbols: *, species only acoustically detected; $\bullet$, species only detected in previous surveys: Haut Marouini (Gaucher \& de Massary 2005b); Haute Wanapi (Gaucher \& de Massary 2005a); Borne 4 (Dewynter \& Chaline 2016); Pic Coudreau du sud (Blanc, 2016), Tumucumaque exp. 2 (Dias Lima 2008).

\begin{tabular}{|c|c|c|c|c|c|c|c|}
\hline Higher taxa & Species & $\begin{array}{l}\text { This } \\
\text { study }\end{array}$ & $\begin{array}{l}\text { Haut } \\
\text { Marouini }\end{array}$ & $\begin{array}{l}\text { Haute } \\
\text { Wanapi }\end{array}$ & Borne 4 & $\begin{array}{l}\text { Pic Coudreau } \\
\text { du sud }\end{array}$ & $\begin{array}{c}\text { Tumucumaque } \\
\text { exp. } 2 \\
\end{array}$ \\
\hline \multicolumn{8}{|l|}{ Anura } \\
\hline Allophrynidae & Allophryne ruthveni Gaige, 1926 & 2 & - & - & - & - & - \\
\hline \multirow[t]{7}{*}{ Bufonidae } & $\begin{array}{l}\text { Amazophrynella teko Rojas, Fouquet, Ron, Hernández- } \\
\text { Ruz, Melo-Sampaio, Chaparro, Vogt, Carvalho, } \\
\text { Pinheiro, Avila, Farias, Gordo \& Hrbek, } 2018\end{array}$ & 8 & - & $\times$ & $\times$ & $x$ & $\times$ \\
\hline & Atelopus hoogmoedi・ Lescure, 1974 & - & - & $x$ & - & $x$ & $x$ \\
\hline & Rhaebo guttatus (Schneider, 1799) & 1 & - & $\times$ & $\times$ & $\times$ & $\times$ \\
\hline & $\begin{array}{l}\text { Rhinella lescurei Fouquet, Gaucher, Blanc \& Vélez- } \\
\text { Rodriguez, } 2007\end{array}$ & 3 & - & $\times$ & - & - & $\times ?$ sp. 1 \\
\hline & $\begin{array}{l}\text { Rhinella martyi Fouquet, Gaucher, Blanc \& Vélez- } \\
\text { Rodriguez, } 2007\end{array}$ & 4 & $\times$ & $x$ & $x$ & $x$ & $\times ?$ sp.2 \\
\hline & Rhinella castaneotica・(Caldwel, 1991) & - & - & - & $x$ & - & - \\
\hline & Rhinella marina・ (Linnaeus, 1758) & - & - & $\times$ & - & - & $\times$ \\
\hline \multirow[t]{7}{*}{ Centrolenidae } & Hyalinobatrachium cappellei (Van Lidth de Jeude, 1904) & 1 & - & $\times$ & - & $\times$ & - \\
\hline & Hyalinobatrachium iaspidiense (Ayarzagüena, 1992) & 2 & - & - & - & - & - \\
\hline & $\begin{array}{l}\text { Hyalinobatrachium kawense Castroviejo-Fisher, Vilà, } \\
\text { Ayarzagüena, Blanc \& Ernst, } 2011\end{array}$ & 2 & - & - & - & - & - \\
\hline & Hyalinobatrachium taylori (Goin, 1968) & 2 & - & - & - & - & - \\
\hline & Hyalinobatrachium mondolfii* Señaris \& Ayarzagüena, 2001 & * & - & - & - & - & - \\
\hline & Vitreorana ritae (Lutz \& Kloss, 1952) & 1 & - & - & $\times$ & - & - \\
\hline & Cochranella geijskezi* (Goin, 1966) & * & - & - & - & - & - \\
\hline \multirow{8}{*}{ Craugastoridae } & Pristimantis chiastonotus (Lynch \& Hoogmoed, 1977) & 2 & - & $\times$ & $\times$ & $\times$ & $x$ \\
\hline & $\begin{array}{l}\text { Pristimantis gutturalis (Hoogmoed, Lynch \& Lescure, } \\
\text { 1977) }\end{array}$ & 3 & - & - & $\times$ & - & $\times$ \\
\hline & Pristimantis inguinalis Parker, 1940 & 3 & - & - & $\times$ & $\times$ & - \\
\hline & Pristimantis cf. zimmermanae* Heyer \& Hardy, 1991 & * & - & - & $\times$ & - & - \\
\hline & Pristimantis sp. 1 & 4 & - & - & $\times$ & $x$ & - \\
\hline & Pristimantis sp. 4 & 5 & - & - & $x$ & $\times$ & - \\
\hline & $\begin{array}{l}\text { Pristimantis aff. pluvialis Shepack, von May, Ttito \& } \\
\text { Catenazzi, } 2016\end{array}$ & 4 & - & - & - & $\times$ & - \\
\hline & Pristimantis zeuctotylus (Lynch \& Hoogmoed, 1977) & 4 & - & $\times$ & $\times$ & $\times$ & - \\
\hline \multirow[t]{6}{*}{ Aromobatidae } & Allobates aff. tapajos Lima, Simões \& Kaefer, 2015 & 3 & - & - & $\times$ & - & - \\
\hline & Allobates femoralis (Boulenger, 1884) & 2 & $\times$ & $\times$ & $x$ & $\times$ & - \\
\hline & $\begin{array}{l}\text { Allobates granti (Kok, MacCulloch, Gaucher, Poelman, } \\
\text { Bourne, Lathrop \& Lenglet, 2006) }\end{array}$ & 4 & $x$ & $x$ & $x$ & - & × ? sp.2 \\
\hline & $\begin{array}{l}\text { Anomaloglossus mitaraka Fouquet, Vacher, Courtois, } \\
\text { Deschamps, Ouboter, Jairam, Gaucher, Dubois \& } \\
\text { Kok, } 2019\end{array}$ & 12 & - & $x$ & $x$ & $x$ & $\times ?$ sp. 1 \\
\hline & $\begin{array}{l}\text { Anomaloglossus baeobatrachus (Boistel \& de } \\
\text { Massary, 1999) }\end{array}$ & 12 & $x$ & $x$ & $x$ & $x$ & $\times ?$ beebei \\
\hline & Anomaloglossus surinamensis Ouboter \& Jairam, 2012 & 6 & - & - & - & $x$ & $\times ?$ sp.3 \\
\hline \multirow[t]{2}{*}{ Dendrobatidae } & Ameerega hahneli (Boulenger, 1884) & 1 & $x$ & $x$ & $x$ & $\times$ & $x$ \\
\hline & Dendrobates tinctorius (Cuvier, 1797) & 3 & - & - & $x$ & $x$ & - \\
\hline \multirow[t]{15}{*}{ Hylidae } & $\begin{array}{l}\text { Dendropsophus counani Fouquet, Orrico, Ernst, } \\
\text { Blanc, Martinez, Vacher, Rodrigues, Ouboter, Jairam } \\
\text { \& Ron, } 2015\end{array}$ & 1 & - & - & - & - & - \\
\hline & Dendropsophus aff. minusculus (Rivero, 1971) & 4 & $\times$ & $\times$ & $x$ & $x$ & - \\
\hline & Boana calcarata (Troschel, 1848) & 2 & - & - & - & - & $x$ \\
\hline & Boana cinerascens (Spix, 1824) & 1 & - & $x$ & $x$ & $x$ & - \\
\hline & Boana dentei (Bokermann, 1967) & 3 & - & $\times$ & $x$ & $\times$ & - \\
\hline & Boana cf. fasciata (Günther, 1858) & 4 & - & - & - & - & - \\
\hline & Boana xerophylla• (Duméril \& Bibron, 1841) & - & $\times$ & $\times$ & $\times$ & - & $\times ?$ sp. 1 \\
\hline & Boana multifasciata・ (Günther, 1859) & - & - & $\times$ & $\times$ & - & - \\
\hline & Boana boans * (Linnaeus, 1758) & * & $x$ & $\times$ & $\times$ & - & $x$ \\
\hline & Osteocephalus leprieurii (Duméril \& Bibron, 1841) & 1 & - & $\times$ & - & - & $x$ \\
\hline & Osteocephalus oophagus Jungfer \& Schiesari, 1995 & 2 & - & $\times$ & $\times$ & $\times$ & $x$ \\
\hline & Osteocephalus taurinus Steindachner, 1862 & 4 & - & - & $\times$ & $\times$ & $\times$ \\
\hline & Scinax sp. 1 & 2 & - & - & - & - & - \\
\hline & $\begin{array}{l}\text { Trachycephalus hadroceps* (Duellman \& Hoogmoed, } \\
\text { 1992) }\end{array}$ & * & - & $x$ & $x$ & $x$ & - \\
\hline & Trachycephalus resinifictrix* (Goeldi, 1907) & * & $x$ & $x$ & $\times$ & $x$ & $x$ \\
\hline \multirow{3}{*}{ Phyllomedusidae } & Phyllomedusa bicolor (Boddaert, 1772) & 1 & - & - & - & - & $x$ \\
\hline & Phyllomedusa vaillanti Boulenger, 1882 & 1 & - & - & - & - & - \\
\hline & Callimedusa tomopterna・ (Cope, 1868) & - & - & - & $\times$ & - & - \\
\hline
\end{tabular}


TABLE 1. - Continuation

\begin{tabular}{|c|c|c|c|c|c|c|c|}
\hline \multicolumn{2}{|c|}{ Leptodactylidae Adenomera andreae Müller, 1923} & 5 & - & $x$ & $x$ & $x$ & $x$ \\
\hline \multirow{13}{*}{ Leptodactylida } & Adenomera heyeri Boistel, De Massary \& Angulo, 2006 & 2 & $x$ & - & $\times$ & $x$ & - \\
\hline & Adenomera hylaedactyla (Cope, 1868) & 3 & - & - & - & - & $x$ \\
\hline & Hydrolaetare schmidti• (Cochran \& Goin, 1959) & - & - & - & - & - & $\times$ \\
\hline & Leptodactylus longirostris Boulenger, 1882 & 1 & $x$ & $\times$ & $x$ & $\times$ & - \\
\hline & Leptodactylus myersi Heyer, 1995 & 3 & $x$ & $x$ & $x$ & $x$ & - \\
\hline & Leptodactylus pentadactylus (Laurenti, 1768) & 1 & - & $x$ & $x$ & $x$ & $x$ \\
\hline & Leptodactylus rhodomystax Boulenger, 1884 & 2 & - & $x$ & $x$ & $x$ & - \\
\hline & Leptodactylus cf. petersii (Steindachner, 1864) & 2 & - & - & - & - & $\times$ ? \\
\hline & Leptodactylus podicipinus species group & 4 & - & - & $x$ & $x$ & - \\
\hline & Leptodactylus stenodema Jiménez de la Espada, 1875 & 2 & - & - & $x$ & - & $x$ \\
\hline & Leptodactylus knudseni• Heyer, 1972 & - & - & - & - & $x$ & - \\
\hline & Leptodactylus mystaceus• (Spix, 1824) & - & - & - & - & - & $x$ \\
\hline & Lithodytes lineatus• (Schneider, 1799) & - & - & $\times$ & $\times$ & - & $\times$ \\
\hline \multirow[t]{3}{*}{ Microhylidae } & $\begin{array}{l}\text { Chiasmocleis aff. haddadi Peloso, Sturaro, Forlani, } \\
\text { Gaucher, Motta \& Wheeler, } 2014\end{array}$ & 2 & - & - & - & - & - \\
\hline & $\begin{array}{l}\text { Synapturanus cf. mirandaribeiroi Nelson \& Lescure, } \\
1975\end{array}$ & 3 & - & - & - & - & $x$ \\
\hline & Otophryne pyburni Campbell \& Clarke, 1998 & 1 & - & $x$ & $x$ & $x$ & - \\
\hline Pipidae & Pipa aspera• Müller, 1924 & * & - & - & $\times$ & $x$ & - \\
\hline \multicolumn{7}{|l|}{ Gymnophiona } & - \\
\hline \multicolumn{2}{|c|}{ RhinatrematidaeRhinatrema bivittatum• (Guérin-Méneville, 1838) } & - & - & - & - & - & $x$ \\
\hline Total & 69 & 57 & 12 & 31 & 41 & 34 & 31 \\
\hline
\end{tabular}

\section{Hyalinobatrachium iaspidiense}

(Ayarzagüena, 1992)

Type LOCALiTy. - Venezuela, Bolivar, Quebrada Jaspe.

Distribution. - Widespread in Amazonia.

TAXONOMIC REMARKS. - The populations from French Guiana unambiguously belong to the nominal species.

Habitat in Mitaraka. - Calling males were heard along the Alama creek.

Material EXAMined. — La Planète Revisitée Guyane 2015, MNHNPNI, APA973-1: AF2767 (ơ); AF2829 (?).

\section{Hyalinobatrachium kawense Castroviejo-Fisher, Vilà,} Ayarzagüena, Blanc \& Ernst, 2011

(Fig. 2D)

TYPE LOCALITY. — French Guiana, rivière de Kaw.

DisTRIBUTION. - Only known from the type locality but recently reported from Sipaliwini, Suriname, some $400 \mathrm{~km}$ away from the previously known distribution (Fouquet et al. 2015b). This knew record stands in between these two areas and confirms that the species is likely much more widespread in the GS than initially thought.

TAXONOMIC REMARKS. - The Mitaraka population unambiguously belongs to the nominal species.

Habitat in MitaraKa. - Calling males were collected in Euterpe Mart. palms along swampy stream beds.

Material eXAMINED. — La Planète Revisitée Guyane 2015, MNHNPNI, APA973-1: AF2759 (ơ); AF2760 (ơ).

MALE CALL. - MNHN-SO-2019-20 (AF2760).

\section{Hyalinobatrachium taylori (Goin, 1968)}

TyPe LOCAlity. - Guyana, New River.

DisTribution. - This GS endemic occurs throughout the region.

TAXONOMIC REMARKS. - Venezuelan populations may correspond to a related species (Castroviejo-Fisher et al. 2011) but the lowland populations as in Mitaraka most likely correspond to the nominal species.

Habitat In MitARAKA. — Many males calling several meters above the Alama creek were heard.

Material eXAMINED. — La Planète Revisitée Guyane 2015, MNHNPNI, APA973-1: AF2834 (ơ); AF2859.

\section{Hyalinobatrachium mondolfii}

Señaris \& Ayarzagüena, 2001

Type LOCAlity. - Venezuela, Caño Acoima, Delta Amacuro.

Distribution. - Widespread in Amazonia.

TAXONOMIC REMARKS. - The populations in French Guiana unambiguously belong to the nominal species.

Habitat In MitaraKA. - Males were heard along the Alama creek but could not be collected.

Material EXAMINED. - NA.

Vitreorana ritae (Lutz, 1952)

Type locality. - Colombia, Amazonas, Río Caiwima, c. $70 \mathrm{~km}$ NNE Puerto Nariño. 
Distribution. - Widespread in Amazonia.

TAXONOMIC REMARKS. - Vitreorana oyampiensis, described from French Guiana is currently considered a junior synonym of Vitreorana ritae (Cisneros-Heredia 2013). However, given the geographical distance from the type locality and French Guiana and the absence of molecular and acoustic data from Colombia we argue that this synonymy remains dubious.

Habitat in MitaraKa. - Several calling males were heard from low height in bushes near flooded areas.

Material EXAMINED. — La Planète Revisitée Guyane 2015, MNHNPNI, APA973-1: AF2787 (ơ).

Family Craugastoridae Hedges,

Duellman \& Heinicke, 2008

Pristimantis chiastonotus (Lynch \& Hoogmoed, 1977)

TyPE LOCALiTY. — Suriname, Brownsberg.

Distribution. - Eastern Guiana Shield: Brazil Amapá, French Guiana, Suriname and Brazil Northern Pará.

TAXONOMIC REMARKS. - This GS endemic displays a marked genetic structure (Fouquet et al. 2012) and probably harbours more than a single species. Until further research, we consider that the population of the Mitaraka massif belongs to the nominal species.

HABitaT In MitaraKa. - It was found throughout the terra firme of the study area generally in small patches associated with disturbance due to fallen trees. Males call at dusk from low elevation in dense undergrowth vegetation.

Material EXAMINED. — La Planète Revisitée Guyane 2015, MNHNPNI, APA973-1: AF2737 (ơ); AF2788 (ơ).

\section{Pristimantis gutturalis}

(Hoogmoed, Lynch \& Lescure, 1977)

Type LOCALITY. - French Guiana, Lower Mataroni River.

Distribution. - Eastern Guiana Shield: Brazil, Amapá, French Guiana, southern Suriname.

TAXONOMIC REMARKS. - The population of the Mitaraka massif unambiguously belongs to the nominal species.

Habitat in MitaraKa. - Two patches of individuals were found on terra firme habitat. The call of this species was recorded for the first time during the survey. They call for only 20-30 min from 4:30 pm perched about $30 \mathrm{~cm}$ above the ground on small plants or on the spines of Astrocaryum palms.

Material EXAMINED. — La Planète Revisitée Guyane 2015, MNHNPNI, APA973-1: AF2736 (J); AF2806; AF2807.

\section{Pristimantis inguinalis (Parker, 1940)}

TyPe LOCALiTY. - Guyana, New River.

Distribution. - Throughout the lowlands of the eastern Guiana Shield (Guyana, Suriname, French Guiana, Brazil Amapá and Northern Para).
TAXONOMIC REMARKS. - The population of the Mitaraka massif unambiguously belongs to the nominal species.

Habitat In MitaraKA. - This species conspicuously calls at dusk from 2-4 m above the ground, on trunks and leaves throughout the study area.

Material eXAminED. — La Planète Revisitée Guyane 2015, MNHNPNI, APA973-1: AF2825 (ơ); AF2826 (ㅇ), AF2858.

MALE CALL. - MNHN-SO-2019-25 (AF2858).

\section{Pristimantis aff. zimmermanae}

(Heyer \& Hardy, 1991)

TYPE LOCALITY. - Brazil, Amazonas, Reservas INPA-WWF-SI, $80 \mathrm{~km}$ North of Manaus.

Distribution. - Supposedly widespread in Amazonia.

TAXONOMIC REMARKS. - This species is poorly known and very difficult to collect. Records outside the type locality remain ambiguous. The population of the Mitaraka massif was only acoustically detected but the call unambiguously corresponds to other populations in French Guiana belonging to a species that we identified as $P$. aff. zimmermanae. However, this identification remains tentative until we can compare with material from the type locality.

HabitaT In MitaraKa. - The species was heard at night in ecotonal low Clusia forest and disturbed patches of vegetation.

Material EXAMINED. - NA.

\section{Pristimantis sp. 1}

Distribution. - This species is endemic to the eastern Guiana Shield.

TAXONOMIC REMARKS. - Fouquet et al. (2013) and later Kok et al. (2018) discuss the status of this species and of $P$. marmoratus with which the former was mixed up with.

Habitat in MitaraKa. - It was found calling at dusk from low vegetation in small patches of individuals, throughout the study area.

Material eXAmined. — La Planète Revisitée Guyane 2015, MNHNPNI, APA973-1: AF2786 (0'); AF2799 (?); AF2815 (\$); AF2816 (\%); AF2860 (o').

MALE CALL. - MNHN-SO-2019-23 (AF2786)

\section{Pristimantis sp. 4}

Distribution. - This species is endemic to the eastern Guiana Shield.

TAXONOMIC REMARKS. - Fouquet et al. (2013) and later Kok et al. (2018) clarified the status of this species and of $P$. marmoratus with which the former was mixed up with.

HabitaT IN MitaraKA. — The call of this species remains unknown but this species was frequently found at night throughout the study area either on the leaf litter or perched on low vegetation.

Material eXamined. — La Planète Revisitée Guyane 2015, MNHN-

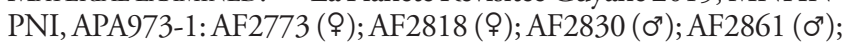
AF2862 (ơ). 


\section{Pristimantis aff. pluvialis \\ Shepack, von May, Ttito \& Catenazzi, 2016}

(Fig. 2E)

Type Locality. - Peru, Región Cusco, Provincia Paucartambo, Distrito Kosñipata, Quitacalzón.

DisTRIBUTION. - This recently described species is only known from the Andean foothills of southern Peru and the Guiana shield populations are only known from the Mitaraka Massif.

TAXONOMIC REMARKS. - The population of this species likely belongs to an undescribed species related to Pristimantis pluvialis. This arboreal species was previously reported from two nearby localities: Mitaraka Nord (Gaucher com. pers), and Pic Coudreau du sud (Blanc 2016) (Fig. 1).

HabitaT in Mitaraka. - It was found calling in large patches near small stream from 3-5 m above the ground in the vegetation notably bamboo patches.

MATERIAL EXAMINED. — La Planète Revisitée Guyane 2015, MNHN-

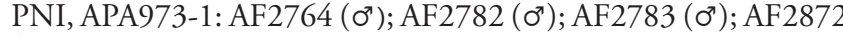
$\left(0^{7}\right)$.

MALE CALL. - MNHN-SO-2019-21 (AF2764).

Pristimantis zeuctotylus (Lynch \& Hoogmoed, 1977)

Type Locality. - Suriname, Nickerie District, Sipaliwini, Vier Gebroeders Mountain.

Distribution. - This species occurs throughout the eastern Guiana Shield.

TAXONOMIC REMARKS. - Several species may exist within what is currently considered as P. zeuctotylus. Until further research, we consider that the population of the Mitaraka massif belongs to the nominal species.

Habitat in MitaraKa. - It was found throughout the study area, generally nearby rotten logs.

MATERIAL eXAmined. - La Planète Revisitée Guyane 2015, MNHNPNI, APA973-1: AF2794; AF2856 (J); AF2857 (ơ); AF2873.

Family AROMOBATidAe Grant, Frost, Caldwell, Gagliardo, Haddad, Kok, Means, Noonan, Schargel \& Wheeler, 2006

Allobates aff. tapajos Lima, Simóes \& Kaefer, 2015

Type locality. - Brazil, Pará, Parque Nacional da Amazônia, Municipality of Itaituba.

Distribution. - On both margins of the Tapajós River.

TAXONOMIC REMARKS. - The population of the Mitaraka massif belongs to a probably undescribed species occurring in the eastern Guiana Shield related to $A$. tapajos.

Habitat In MitaraKa. - This species is associated with the banks of small rivers. A small patch of calling males was found near the Alama creek.

Material EXAMineD. — La Planète Revisitée Guyane 2015, MNHNPNI, APA973-1: AF2789; AF2828 (ơ); AF2855.
Allobates femoralis (Boulenger, 1884)

TyPe LOCALITY. — Yurimaguas, Huallaga River, Loreto, Peru.

Distribution. - Throughout Amazonia.

TAXONOMIC REMARKS. - This widespread species represents a species complex with noticeable differences in call, morphology, and genetics (Amézquita et al. 2009). The populations of the Guiana Shield display several mitochondrial lineages, all distinct from the populations from Peru (Fouquet et al. 2012). Therefore, we suspect that the population of the Mitaraka massif may not correspond to the nominal species.

Habitat in MitaraKa. - This species was found conspicuously calling throughout the study area.

Material eXamined. — La Planète Revisitée Guyane 2015, MNHNPNI, APA973-1: AF2781; AF2819 ().

Allobates granti (Kok, MacCulloch, Gaucher, Poelman, Bourne, Lathrop \& Lenglet, 2006)

TyPe Locality. — French Guiana, Saül.

Distribution. - Eastern Guiana Shield, although remarkably absent from brazilian northern Amapá.

TAXONOMIC REMARKS. - This species harbours a marked genetic structure between the Surinamese, the French Guiana, and the northern Pará populations that may suggest the existence of several species. However, the population of the Mitaraka massif unambiguously belongs to the nominal species.

Habitat in MitaraKa. - It is associated to swampy streams where it deposits its tadpoles. Males were heard conspicuously calling from the surroundings of these swampy streams throughout the study area.

Material eXAMINED. — La Planète Revisitée Guyane 2015, MNHNPNI, APA973-1: AF2728 (ơ); AF2744; AF2768 (ơ); AF2836 (\%).

MALE CALL. — MNHN-SO-2019-17 (AF2728).

Anomaloglossus mitaraka Fouquet, Vacher, Courtois, Deschamps, Ouboter, Jairam, Gaucher, Dubois \& Kok, 2019

(Fig. 2B)

TYPe LOCALITY. - French Guiana, Mitaraka massif.

Distribution. - This species is only known from the Mitaraka massif and its vicinity in Suriname.

TAXONOMIC REMARKS. - This species is distinguished morphologically and acoustically from the closely related $A$. baeobatrachus (Boistel \& Massary, 1999) also occurring in the Mitaraka massif, and has a different larval development mode (Vacher et al. 2017, Fouquet et al. 2019a, b).

HABITAT IN MitARAKA. - It is associated with swampy streams where it deposits its tadpoles. Males were heard conspicuously calling from the surroundings of these swampy streams throughout the study area.

Material eXAMINED. — La Planète Revisitée Guyane 2015, MNHNPNI, APA973-1: AF2724 (MNHN-RA-2018-71 ه7); AF2731

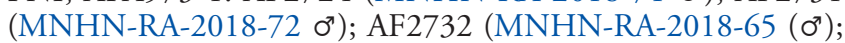
AF2748 (ơ); AF2750 (MNHN-RA-2018-66 ơ); AF2751 (MNHN- 
RA-2018-67 ơ); AF2754 (MNHN-RA-2018-68 ơ); AF2808 (MNHN-RA-2018-69 ơ); AF2814 (MNHN-RA-2018-64 o'); AF2824 (MNHN-RA-2018-73 ơ); AF2875 (T); AF2878 (MNHNRA-2018-70 o').

Male Call. - MNHN-SO-2019-15 (AF2732, MNHNRA-2018-65).

\section{Anomaloglossus baeobatrachus}

(Boistel \& Massary, 1999)

Type LOCAlity. - French Guiana, Saint Eugène.

Distribution. - Eastern Guiana Shield (French Guiana, Southeastern Suriname, Brazil Amapá)

TAXONOMIC REMARKS. - Several populations throughout the Guiana Shield have been erroneously attributed to this species which only occurs in the easternmost part of the Guiana Shield.

Habitat in MitaraKa. - This species was found throughout the terra firme of the study area.

MATERIAl EXAMINED. — La Planète Revisitée Guyane 2015, MNHN-

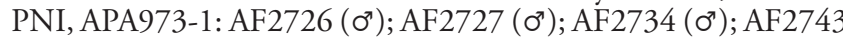

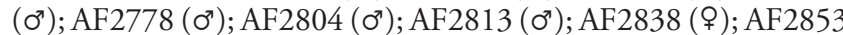
(\%); $\operatorname{AF} 2876\left(0^{7}\right) ; \operatorname{AF} 2877\left(0^{7}\right)$

MALE CALL. - MNHN-SO-2019-16 (AF2734).

\section{Anomaloglossus surinamensis}

Ouboter \& Jairam, 2012

Type locality. — Suriname, Nassau Mountain, Paramacca Creek.

Distribution. - Eastern Guiana Shield, although not occurring east of the Approuague River in French Guiana and not reported from Brazil Amapá.

TAXONOMIC REMARKS. - This species harbours a pronounced genetic structure however no major differences in calls or morphology have been found across populations (Vacher et al. 2017). Therefore, the population of the Mitaraka massif are identified as the nominal species.

Habitat in MitaraKA. - This species is associated to stream headwaters and several patches of individuals were found in the study area.

Material EXAMINED. — La Planète Revisitée Guyane 2015, MNHN-

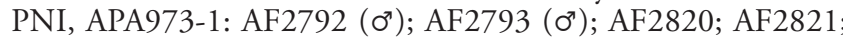
AF2822; AF2879 (o')

\section{Family Dendrobatidae Cope, 1865}

Ameerega habneli (Boulenger, 1884)

Type LoCality. — Peru, Loreto, Yurimaguas, Huallaga River.

DisTRIBUTION. - Throughout Amazonia, although remarkably absent from northern Suriname and Guyana.

TAXONOMIC REMARKS. - This widespread species likely represents a species complex. However, until further research is available the GS populations are assigned to the nominal species.
Habitat in Mitaraka. - Ameerega hahneli is associated to swampy streams where it deposits its tadpoles. Males were heard conspicuously calling from the surroundings of these swampy streams throughout the study area.

Material eXAmined. — La Planète Revisitée Guyane 2015, MNHNPNI, APA973-1: AF2745 (ơ); AF2854 ().

\section{Dendrobates tinctorius (Cuvier, 1797)}

TYPE LOCALITY. — "Amérique" (without precision).

Distribution. — Guiana Shield.

TAXONOMIC REMARKS. - This species occurs in isolated patches associated with small massifs throughout the Guiana Shield although absent from northern Guyana and northern Suriname.

Habitat in MitaraKa. - It was found throughout the terra firme of the study area.

Material eXAmined. — La Planète Revisitée Guyane 2015, MNHNPNI, APA973-1: AF2725; AF2746; AF2747; AF2749 (T).

\section{Family HyLIDAE Rafinesque, 1815}

\section{Dendropsophus counani}

Fouquet, Orrico, Ernst, Blanc, Martinez, Vacher, Rodrigues, Ouboter, Jairam \& Ron, 2015

TyPe LOCAlity. - French Guiana, Grande Montagne Tortue, municipality of Régina.

Distribution. — Lowlands of the Eastern Guiana Shield.

TAXONOMIC REMARKS. - The population of the Mitaraka massif unambiguously belongs to the nominal species.

Habitat in Mitaraka. - A single clutch of this species was found on the vegetation overhanging a pond nearby the Alama creek.

Material eXAmined. — La Planète Revisitée Guyane 2015, MNHNPNI, APA973-1: AF2848 (T).

\section{Dendropsophus aff. minusculus (Rivero, 1971)}

TYPE LOCALITY. — Venezuela, Nirgua, Edo. Yaracay.

Distribution. - Dendropsophus minusculus is associated with small patches of vegetation in open habitats of northern South America. It belongs to a very complex species group and many populations assigned to this species may have been misidentified. Therefore, the distribution of this species remains poorly delimited.

TAXONOMIC REMARKS. - Populations of the Guiana Shield associated to forest habitat, like in the Mitaraka massif, harbour a distinct mitochondrial lineage that probably corresponds to a distinct species.

Habitat in MitaraKa. — This species was conspicuously calling from the vegetation after rainfall along swampy streams and ponds formed nearby the creeks.

Material eXAmined. — La Planète Revisitée Guyane 2015, MNHN-

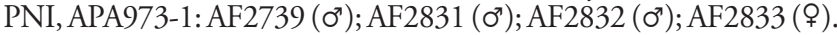


Boana calcarata (Troschel, 1848)

Type LOCALITY. — Guyana.

Distribution. - Widespread in Amazonia.

TAXONOMIC REMARKS. - The population of the Mitaraka massif unambiguously belongs to the nominal taxon.

HABITAT In MitARAKA. - This species was found along the rivers, often calling from the vegetation overhanging flooded areas.

Material EXAMINED. — La Planète Revisitée Guyane 2015, MNHNPNI, APA973-1: AF2849 (ơ); AF2850 (ơ).

\section{Boana cinerascens (Spix, 1824)}

TyPe LOCALiTy. - Brazil, Tefé, Amazonas.

Distribution. - Widespread in Amazonia.

TAXONOMIC REMARKS. - This is a large species complex and the populations of French Guiana may belong to an undescribed species.

Habitat In MitaraKa. - Boana cinerascens is associated to swampy streams. Males were heard calling at low elevation in the vegetation or on the ground of several streams in the study area.

Material EXAMINED. — La Planète Revisitée Guyane 2015, MNHNPNI, APA973-1: AF2780.

Boana dentei (Bokermann, 1967)

TyPe LOCAliTy. - Brazil, Amapá, Serra do Navio.

Distribution. — Eastern Guiana Shield.

TAXONOMIC REMARKS. - The population of the Mitaraka massif unambiguously belongs to the nominal species.

HabitaT In MitaraKa. - It was found in all the swampy streams of the study area.

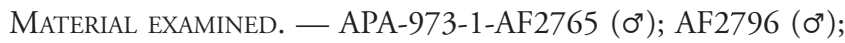
AF2797 (ㅇ).

\section{Boana cf. fasciata (Günther, 1858)}

Type Locality. - Ecuador, Slopes of the Ecuadorian Andes.

Distribution. - Amazonian slopes of the Andes of Ecuador and Northern Peru.

TAXONOMIC REMARKS. - Caminer \& Ron (2014) redescribed Boana fasciata and demonstrated that it has a restricted distribution on the slopes of the Andes. The other populations previously referred to as $B$. fasciata in the Guiana Shield are more closely related to the clade formed by B. tetete (Caminer \& Ron, 2014) and B. alfaroi (Caminer \& Ron, 2014) that are also restricted to western Amazonia. Therefore, the Guiana Shield populations of this species probably belong to an undescribed species.

Habitat In MitaraKa. - This species was only found on the vegetation surrounding a small pond formed nearby the Alama creek.

Material EXAMINED. — La Planète Revisitée Guyane 2015, MNHN-

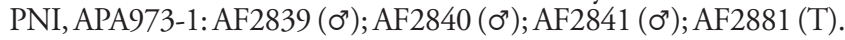

Boana boans (Linnaeus, 1758)

TYPE LOCALITY. - Unknown.

Distribution. - Widespread in Amazonia.

TAXONOMIC REMARKS. - Boana boans is considered as a widespread species but without precise type locality or type material. Therefore, the identification of the Mitaraka population remains tentative.

Habitat IN MitaraKa. - This species was only heard calling from the trees along the Alama Creek and was not collected.

Material eXAMined. - NA.

\section{Osteocephalus leprieurii (Duméril \& Bibron, 1841)}

Type locality. - French Guiana, Cayenne.

DisTribution. — Throughout the Guiana Shield.

TAXONOMIC REMARKS. - The population of the Mitaraka massif unambiguously belongs to the nominal species.

Habitat in Mitaraka. - A single specimen was found in the underwood at night. This species is an explosive breeder and only wandering individuals can be found when not breeding.

Material eXAmined. — La Planète Revisitée Guyane 2015, MNHNPNI, APA973-1: AF3297.

\section{Osteocephalus oophagus Jungfer \& Schiesari, 1995}

TYPe LOCALITY. — Brazil, Amazonas, Reserva Florestal Adolfo Ducke. Distribution. — Throughout the Guiana Shield.

TAXONOMIC REMARKS. - The eastern and the western populations of this species harbour are genetically distinct and may represent distinct species (Jungfer et al. 2013). Therefore, the population of French Guiana may not belong to the nominal species.

Habitat in MitarakA. - This species was heard calling from tree holes and epiphytes throughout the study area.

Material eXAmined. — La Planète Revisitée Guyane 2015, MNHNPNI, APA973-1: AF2770; AF2842.

Osteocephalus taurinus Steindachner, 1862

Type LOCAlity. - Brazil, Amazonas, Manaus.

Distribution. - Widespread in Amazonia.

TAXONOMIC REMARKS. - This is a vast species complex and the population from French Guiana probably belongs to an undescribed species (Jungfer $e t$ al. 2013).

Habitat in MitaraKa. - This is an explosive breeder and several individuals were found wandering in the underwood throughout the study area.

Material examined. - La Planète Revisitée Guyane 2015, MNHN-PNI, APA973-1: AF2755 (J); AF2756 (ơ); AF2757 (\%); AF2883 (T). 


\section{Scinax sp. 1}

Distribution. - This species is known only from a few populations in French Guiana, Brazil Amapá, and Suriname.

TAXONOMIC REMARKS. - This species is most likely an undescribed species related to Scinax wandae and S. cruentommus (Ferrao et al. 2016).

HABITAT IN MiTARAKA. — Only three males were heard calling after heavy rainfall in bushes flooded in the Alama creek.

Material EXAMINED. — La Planète Revisitée Guyane 2015, MNHNPNI, APA973-1: AF2784 (ơ); AF2785 (ơ).

\section{Trachycephalus hadroceps}

(Duellman \& Hoogmoed, 1992)

TYPE LOCALITY. - Guyana, Rupununi District, west of New River, North of Acarai Mountains.

Distribution. - Eastern Guiana Shield.

TAXONOMIC REMARKS. - The population of French Guiana most likely belongs to the nominal species.

Habitat In MitaraKa. - This species was heard calling from the canopy throughout the study area but was not collected.

MATERIAL EXAMINED. — NA.

Trachycephalus resinifictrix (Goeldi, 1907)

Type LOCALITy. - Brazil, Pará, River Maracanã, Mission of San Antonio do Prata.

Distribution. - Guianas and eastern Amazonia.

TAXONOMIC REMARKS. - The conspecificity of the populations on each side of the Amazon River remains to be tested but material in collection is scarce.

Habitat In MitaraKa. - This species was heard calling from the canopy throughout the study area but was not collected.

MATERIAL EXAMINED. — NA.

Family PHYLlOMEDUSIDAE Günther, 1858

Phyllomedusa bicolor (Boddaert, 1772)

TYPE LOCALITY. — Suriname.

Distribution. - Widespread in Amazonia.

TAXONOMIC REMARKS. - The population of the Mitaraka massif unambiguously belongs to the nominal species.

Habitat IN MitaraKa. - A single individual has been heard calling from several meters above the ground and was collected.

MATERIAL EXAMINED. — La Planète Revisitée Guyane 2015, MNHNPNI, APA973-1: AF2835 (0).
Phyllomedusa vaillanti Boulenger, 1882

TYPe LOCALITY. — Brazil, Pará, Santarem.

Distribution. - Widespread in Amazonia.

TAXONOMIC REMARKS. - This is likely a species complex and the populations of the Guiana Shield may represent a species distinct from Phyllomedusa vaillanti.

Habitat in Mitaraka. - A single individual has been found wandering in the forest.

Material eXamined. — La Planète Revisitée Guyane 2015, MNHNPNI, APA973-1: AF2800.

\section{Family LEPTODACTYLIDAE Werner, 1896}

Adenomera andreae (Müller, 1923)

TyPe LOCALITY. — Brazil, Parà, Peixeboi.

Distribution. - Widespread in Amazonia.

TAXONOMIC REMARKS. - Fouquet et al. (2014) showed that several species were hidden under this name. Nevertheless, $A$. andreae remains vastly distributed in Amazonia and likely corresponds to a species complex within which the Guiana Shield populations may correspond to an undescribed species.

HabitaT In Mitaraka. - It was found abundant throughout the study area.

Material EXAMined. — La Planète Revisitée Guyane 2015, MNHN-

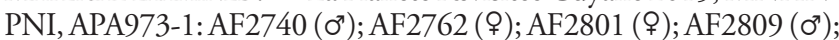
AF2827 ().

MALE CALL. - MNHN-SO-2019-24 (AF2809).

Adenomera heyeri Boistel, Massary \& Angulo, 2006

Type LOCALITY. — French Guiana, Saint-Eugene.

Distribution. - Eastern Guiana Shield.

TAXONOMIC REMARKS. - The population of the Mitaraka Massif unambiguously belongs to the nominal species.

Habitat in MitaraKa. - It was found throughout the study area.

Material eXAmined. — La Planète Revisitée Guyane 2015, MNHN-

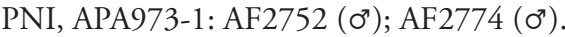

\section{Adenomera cf. hylaedactyla (Cope, 1868)}

(Fig. 2A)

TyPe LOCAlity. — Peru, Napo or upper Maranon River.

Distribution. - Throughout Amazonia, cerrado and northern Brazil.

TAXONOMIC REMARKS. - Fouquet et al. (2014) showed that this species is most likely a species complex but the status of the French Guiana population remains unresolved.

Habitat in Mitaraka. - This species was only found on an inselberg. It is intriguing because previous records in French Guiana are restricted to the coastal savannahs and disturbed areas. Only 
the inselbergs close to the coast harbour population of this species. However, Avila-Pires et al. (2010) reported the species from an interior savannah in Brazil Northern Para and this population is profoundly divergent from the French Guiana coastal populations (Fouquet et al. 2014). Therefore, this record may correspond to an undescribed species reaching French Guiana from the South.

Material EXAMINED. — La Planète Revisitée Guyane 2015, MNHNPNI, APA973-1: AF2868 (ơ); AF2869 (ơ); AF2870 (ơ).

\section{Leptodactylus longirostris Boulenger, 1882}

TyPE LOCALITY. — Brazil, Santarem, Pará.

Distribution. — Brazil, Santarem region and eastern Guiana Shield.

TAXONOMIC REMARKS. - The conspecificity of the populations from each side of the Amazon river remains to be tested and the Guiana Shield populations may represent an undescribed species.

Habitat In MitaraKa. - This species was only found on inselbergs in the study area.

Material eXAMINED. — La Planète Revisitée Guyane 2015, MNHNPNI, APA973-1: AF2871 (o').

\section{Leptodactylus myersi Heyer, 1995}

TyPe Locality. — Brazil, Mucajaí, Roraima.

Distribution. — Eastern Guiana Shield.

TAXONOMIC REMARKS. - The population of the Mitaraka massif unambiguously belongs to the nominal species.

Habitat In MitaraKa. - This species was only found on inselbergs and rocky outcrops in the study area.

MATERIAL EXAMINED. — La Planète Revisitée Guyane 2015, MNHNPNI, APA973-1: AF2772; AF2837 (J); AF2851.

\section{Leptodactylus pentadactylus (Laurenti, 1768)}

TYPe LOCALITY. — Suriname, Lely Mountains.

Distribution. — Throughout Amazonia.

TAXONOMIC REMARKS. - The population of the Mitaraka massif unambiguously belongs to the nominal species.

Habitat in MitaraKa. - It was found wandering on the forest ground throughout the study area.

Material EXAMINED. — La Planète Revisitée Guyane 2015, MNHNPNI, APA973-1: AF2742.

\section{Leptodactylus rhodomystax Boulenger, 1884}

TyPE LOCALiTY. — Northern Peru, Loreto, Yurimaguas, Huallaga River.

Distribution. - Throughout Amazonia.

TAXONOMIC REMARKS. - This species likely represents a species complex within which the Guiana Shield population may belong to a different species.
Habitat in MitaraKa. - It was found wandering on the forest ground throughout the study area.

Material EXAMINED. — La Planète Revisitée Guyane 2015, MNHNPNI, APA973-1: AF2775 (o'); AF2776.

Leptodactylus cf. petersii (Steindachner, 1864)

TyPe LOCALITY. — Brazil, Amazonas, Marabitanas.

Distribution. - Throughout Amazonia.

TAXONOMIC REMARKS. - This is a notoriously confusing taxon with many species erroneously identified under this name. Until a revision of that group is available the populations of the Guiana Shield are only tentatively identified as such.

Habitat in MitaraKa. - It was found associated to swampy areas near streams.

Material eXAMINED. — La Planète Revisitée Guyane 2015, MNHNPNI, APA973-1: AF2795 (J); AF2843 (ơ).

\section{Leptodactylus sp. gr. podicipinus}

TYPE LOCALITY. - NA.

Distribution. - Eastern Guiana Shield.

TAXONOMIC REMARKS. - This is an undescribed species endemic to the eastern Guiana Shield (Fouquet et al. 2012).

Habitat in MitaraKa. - It was found near several small bodies of water in the study area.

Material eXAmined. — La Planète Revisitée Guyane 2015, MNHN-

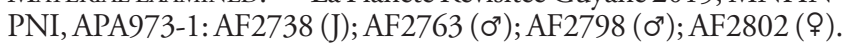

MALE CALL. - MNHN-SO-2019-19 (AF2763).

Leptodactylus stenodema Jiménez de la Espada, 1875

Type locality. - Ecuador, Napo, San José de Moti.

Distribution. - Widespread in Amazonia.

TAXONOMIC REMARKS. - This species likely represents a species complex within which the Guiana Shield population may belong to a different species.

Habitat In Mitaraka. - Only two individuals of this species were found wandering on the forest ground at night.

Material eXamined. — La Planète Revisitée Guyane 2015, MNHNPNI, APA973-1: AF2769 (J); AF3298 (?).

\section{Family MiCROHYLIDAE Günther, 1858}

Chiasmocleis aff. haddadi Peloso, Sturaro, Forlani, Gaucher, Motta \& Wheeler, 2014

(Fig. 2C)

TYPE LOCALITY. — French Guiana, Kotika Montains.

Distribution. - Easternmost part of the Guiana Shield. 
TAXONOMIC REMARKS. - The population of the Mitaraka massif belongs to an undescribed species related to $C$. haddadi. This last species has been reported from southern French Guiana and Brazil Amapá and even later from Sipaliwini (Fouquet et al. 2015b). However, the records from Amapá, southern French Guiana and this new record from Mitaraka correspond to a different species clearly distinct morphologically and acoustically from $C$. haddadi. In Mitaraka, we only found juveniles, and identification was confirmed using molecular data (AF, pers. obs.).

Habitat in Mitaraka. - Two juveniles were collected from the leaf litter near an uncollected calling male.

Material EXAMINED. — La Planète Revisitée Guyane 2015, MNHNPNI, APA973-1: AF2880 (J); AF3296 (J).

\section{Otophryne pyburni Campbell \& Clarke, 1998}

Type locality. - Colombia, Vaupés, Wacará.

Distribution. - From eastern to western Guiana Shield.

TAXONOMIC REMARKS. - This species likely represents a species complex within which the Eastern Guiana Shield populations may belong to a different species.

Habitat in Mitaraka. - This diurnal species was heard in the sandy stream throughout the study area.

MATERIAL EXAMINED. — La Planète Revisitée Guyane 2015, MNHNPNI, APA973-1: AF2777 ( (7).

MALE CALL. - MNHN-SO-2019-22 (AF2777).

\section{Synapturanus cf. mirandaribeiroi Nelson \& Lescure, 1975}

(Fig. 2F)

Type LOCAliTy. - Guyana, Rupununi District, upper Essequibo River, Kanashen.

Distribution. — Northern Amazonia.

TAXONOMIC REMARKS. - Several populations have been identified as $S$. mirandaribeiroi but these identifications remain dubious and a revision of this genus is needed. The populations of the Mitaraka massif are also only tentatively assigned to this taxon. Other records of this genus in French Guiana correspond to a different species with clear differences in morphology and calls (pers. obs.).

Habitat In Mitaraka. - Patches of individuals of this species were found calling from underground after heavy rainfall in two places in the study area, in the forest surrounding a rocky outcrop and in a terra firme with sandy soil.

Material eXAMINED. — La Planète Revisitée Guyane 2015, MNHNPNI, APA973-1: AF2791 (ơ); AF2844 (ơ); AF2845 (ㅇ).

Family SiPHONOPIDAE Bonaparte, 1850

Microcaecilia cf. rochai Maciel \& Hoogmoed, 2011

(Fig. 2G)

Type LOCAlity. — Brazil, Pará, Reserva Pacanari.
Distribution. - Brazil northern Pará, Amapá and southwest French Guiana.

TAXONOMIC REMARKS. - This genus is particularly diversified in the GS and no less than nine species have been described since 2010. Many of these species are known only from their type locality. The two collected specimens superficially fit with the description of Microcaecilia rochai. Nevertheless, we only tentatively assign the collected specimens to $M$. rochai until further examination.

Habitat In MitaraKa. - Two specimens of this species were found by other biologists looking for soil fauna.

Material eXAmined. — La Planète Revisitée Guyane 2015, MNHNPNI, APA973-1: AF2846; AF2866.

\section{DISCUSSION}

Most of the amphibian species recorded during this survey are also occurring throughout French Guiana. However, six of the species detected are only known from the southernmost part of the territory (Anomaloglossus mitaraka, Atelopus hoogmoedi Lescure, 1974, Pristimantis aff. pluvialis, Synapturanus cf. mirandaribeiroi, Rhinella martyi, Microcaecilia cf. rochai) and some may have been discovered during this survey. They are probably more widespread in the interior of Guiana Shield but certainly have a range boundary in French Guiana. A few other species found in the Mitaraka massif represent range extensions. We highlight seven species in particular that are particularly noteworthy:

- The occurrence of Adenomera cf. hylaedactyla is noteworthy because it is very distant from the closest records on the coast of French Guiana. It was found with Leptodactylus longirostris and L. myersi, two species also associated with inselbergs. However, we did not found Boana xerophylla despite the fact that it occurs nearby and that it represents another species associated with inselbergs.

- Anomaloglossus mitaraka has been discovered from previous surveys in the area but we had the opportunity to collect a series of individuals, call records and larvae that allowed the description of this narrowly distributed species.

- The occurrence of Chiasmocleis aff. haddadi is also very interesting as previous records are from Amapá and southeastern French Guiana. We thus extend the range of this undescribed species.

- Hyalinobatrachium kawense was previously known from northern French Guiana and southern Suriname. Therefore, this new record fills a distribution gap and suggests that the species may be distributed throughout Suriname and French Guiana.

- Pristimantis aff. pluvialis was previously discovered from a nearby area (Blanc 2016). During our survey we added new material (specimens, call records) and our observations i.e., the conspicuousness of the calling activity, suggest that this species is likely restricted to the interior of the Eastern Guiana Shield, if not to the Mitaraka massif.

- Similarly, Synapturanus cf. mirandaribeiroi is likely restricted to the southwest corner of French Guiana (the other populations of Synapturanus of French Guiana belong 
to a different species). Synapturanus cf. mirandaribeiroi also occurs in Suriname (pers. obs.) and may extend to the type locality but further research is needed to confirm this hypothesis.

- The two specimens of Microcaecilia discovered during the survey may belong to an undescribed species related to Microcaecilia rochai that may be restricted to the Mitaraka massif.

Most of the 12 species that were found during previous surveys in nearby localities certainly also occur in the Mitaraka massif such as Atelopus hoogmoedi or Callimedusa tomopterna (Cope, 1868). They may have been missed in the present survey. However, this is not the case of Rhinella castaneotica (Caldwel, 1991) which was only found at Borne 4 (60 km East of Mitaraka, Fig. 1) and does not seem to occur further west as this species was not found in any other surveys. Therefore, this species most likely displays a range limit between Mitaraka and Borne 4. This is also very unlikely for Hydrolaetare schmidti (Cochran \& Goin, 1959), an aquatic leptodactylid found in a rather nearby locality in the Tumucumaque Mountain National Park in Amapá (Dias lima 2008) (Fig. 1) as this species is only known in French Guiana from coastal swamp. This population from Amapá is very surprising and probably inhabits an isolated patch of swamp, a very rare habitat in the interior of the Guiana Shield and that we did not find during our survey. Therefore, from other surveys we can hypothesize that the amphibian community occurring in the Mitaraka massif probably reaches at least 69 species. Nevertheless, this number still remains likely underestimated given some explosive breeders such as Scinax proboscideus (Brongersma, 1933); S. aff. ruberoculatus Ferrão, Fraga, Moravec, Kaefer \& Lima, 2018; Trachycephalus coriaceus (Peters, 1867); Dendropsophus leucophyllatus (Beireis, 1783); D. minutus (Peters, 1872); Chiasmocleis shudikarensis Dunn, 1949; Ceratophrys cornuta (Linnaeus, 1758); Hamptophryne boliviana (Parker, 1927); and Ctenophryne geayi Mocquard, 1904. These species are widespread in the GS but could not be found in the present survey because we failed to find any temporary ponds on terra firme which most likely exist in the area given we found Osteocephalus leprieurii. Therefore, the amphibian community of the Mitaraka massif could harbour more than 75 species and represent one of the richest amphibian faunas of the Guiana Shield.

\section{Acknowledgements}

All the material we referred to was collected during the "Our Planet Reviewed" Guyane-2015 expedition in the Mitaraka range, in the core area of the French Guiana Amazonian Park, organized by the MNHN and Pro-Natura international. The expedition was funded by the European Regional Development Fund (ERDF), the Conseil régional de Guyane, the Conseil général de Guyane, the Direction de l'Environnement, de l'Aménagement et du Logement and by the Ministère de l'Éducation nationale, de l'Enseignement supérieur et de la Recherche. It was realized in collaboration with the Parc amazonien de Guyane. We also acknowledge support from an 'Investissement d'Avenir' grant managed by Agence nationale de la Recherche (CEBA, ref. ANR-10-LAB×-25-01). We are grateful for the comments from two anonymous reviewers for scrutinous revision of this manuscript.

\section{REFERENCES}

Amézquita A., lima A. P., Jehle R., Castellanos L., Ramos O., Crawford A. J., Gasser H. \& HÖDL W. 2009. - Calls, colours, shape, and genes: a multi-trait approach to the study of geographic variation in the Amazonian frog Allobates femoralis. Biological Journal of the Linnean Society 98: 826-838. https://doi. org/10.1111/j.1095-8312.2009.01324.x

Avila-Pires T. C. S., Hoogmoed M. S. \& Rocha W. A. 2010. Notes on the vertebrates of northern Pará, Brazil: a forgotten part of the Guianan Region, I. Herpetofauna. Boletim do Museu Paraense Emílio Goeldi. Ciências Naturais 5 (1): 13-112.

BlanC M. 2016. - Inventaire herpétologique du Pic Coudreau du Sud. Les cahiers scientifiques du Parc Amazonien de Guyane 2 (1): 327-339.

Caminer M. A., Mila B., Jansen M., Fouquet A., Venegas P. J., Chavez G., Lougheed S. C. \& Ron S. R. 2017. - Systematics of the Dendropsophus leucophyllatus species complex (Anura: Hylidae): cryptic diversity and the description of two new species. PLoS One 12(3), e0171785. https://doi.org/10.1371/journal. pone. 0171785

CAMiner M. \& RON S. R. 2014. - Systematics of treefrogs of the Hypsiboas calcaratus and Hypsiboas fasciatus species complex (Anura, Hylidae) with the description of four new species. ZooKeys 370: 1-68. https://doi.org/10.3897/zookeys.370.6291

Castroviejo-Fisher S., Vila C., Ayarzagueena J., Blanc M. \& ERNST R. 2011. - Species diversity of Hyalinobatrachium glassfrogs (Amphibia: Centrolenidae) from the Guiana Shield, with the description of two new species. Zootaxa 3132: 1-55. https:// doi.org/10.11646/zootaxa.3132.1.1

Cisneros-Heredia D. F. 2013. - Centrolene ritae Lutz is a senior synonym of Cochranella oyampiensis Lescure and Cochranella ametarsia Flores (Anura: Centrolenidae). Avances en Ciencias e Ingenierias. Sección B 5 (2): B1-B4. https://doi.org/10.18272/ aci.v5i2.132

DeWynter M. \& Chaline O. 2016. - Inventaire herpétologique de la Borne $\mathrm{n}^{\circ} 4$. Les cabiers scientifiques du Parc Amazonien de Guyane 2 (1): 281-302.

Dias Lima J. 2008. - A herpetofauna do Parque Nacional do Montanhas do Tumucumaque, Amapá, Brasil, Expediçóes I a V. in BERnARD E. (Ed.), Inventários Biológicos Rápidos no Parque Nacional Montanhas do Tumucumaque, Amapá, Brasil. RAP Bulletin of Biological Assessment 48: 38-50.

Duellman W. E. \& Hoogmoed M. S. 1992. — Some hylid frogs from the Guiana Highlands, northeastern South America: New species, distributional records, and a generic reallocation. Occasional Papers of the Museum of Natural History, University of Kansas 147: 1-21.

Ferrão M., Colatreli O., De Fraga R., Kaefer I. L., Moraved J. \& LimA A. P. 2016. - High species richness of Scinax Treefrogs (Hylidae) in a threatened amazonian landscape revealed by an integrative approach. PLoS ONE 11(11), p.e0165679. https:// doi.org/10.1371/journal.pone.0165679

Fouquet A., Gaucher P., Blanc M. \& Vélez-Rodriguez C. M. 2007a. - Description of two new species of Rhinella (Anura: Bufonidae) from the lowlands of the Guiana Shield. Zootaxa 1663: 17-32.

Fouquet A., Gilles A., Vences M., Marty C., Blanc M. \& GEMMELL N. J. 2007b. — Underestimation of species richness in Neotropical frogs revealed by mtDNA analyses. PLoS ONE 2 (10), e1109. https://doi.org/10.1371/journal.pone.0001109 
Fouquet A., Noonan B. P., Rodrigues M. T., Pech N., Gilles A. \& GEMMELL N. J. 2012. - Multiple quaternary refugia in the eastern Guiana Shield revealed by comparative phylogeography of 12 frog species. Systematic Biology 61: 461-489. https://doi. org/10.1093/sysbio/syr130

Fouquet A., Martinez Q., Courtois E. A., Dewynter M., Pineau K., Gaucher P., Blanc M., Marty C. \& KoK P. J. R. 2013. - A new species of the genus Pristimantis (Amphibia, Craugastoridae) associated with the moderately evelated massifs of French Guiana. Zootaxa 3750: 569-586. https://doi. org/10.11646/zootaxa.3750.5.8

Fouquet A., Cassini C., Haddad C. F. B., Pech N. \& Rodrigues M. T. 2014. - Species delimitation, patterns of diversification and historical biogeography of a Neotropical frog genus; Adenomera (Anura, Leptodactylidae). Journal of Biogeography 41 (5): 855-870.

Fouquet A., Orrico V. G. D., ERnst R., Blanc M., Martinez Q., Vacher J.-P., Rodrigues M. T., Ouboter P., Jairam R., RoN S. 2015a. - A new Dendropsophus Fitzinger, 1843 (Anura: Hylidae) of the parviceps group from the lowlands of the Guiana Shield. Zootaxa 4052 (1): 39-64. https://doi.org/10.11646/ zootaxa.4052.1.2

Fouquet A., Vacher J.-P., Kadosoe V., Jairam R. \& Ouboter P. 2015b. - Checklist of the Amphibians of the Sipaliwini area, Suriname. Herpetology Notes 8: 63-68.

Fouquet A., Martinez Q., Zeidler L., Courtois E. A., Gaucher P., Blanc M., Dias lima J., Marques Souza S., Rodrigues M. \& KOK P. J. R. 2016. - Cryptic diversity in the Hypsiboas semilineatus species group (Amphibia, Anura) with the description of a new species from the eastern Guiana Shield. Zootaxa 4084(1): 079-104. https://doi.org/10.11646/zootaxa.4084.1.3

Fouquet A., Vacher J.-P., Courtois E. A., Deschamps C., Ouboter P., Jairam R., Gaucher P., Dubois A. \& KoK P. J. R. 2019a. - A new species of Anomaloglossus (Anura: Aromobatidae) of the stepheni group with the redescription of Anomaloglossus baeobatrachus (Boistel and de Massary, 1999), and an amended diagnosis of $A$. leopardus (Ouboter and Jairam, 2012). Zootaxa 4576 (3): 439-460. https://doi.org/10.11646/ zootaxa.4576.3.2

Fouquet A., Ferrier B., Salmona J., Tirera S., Vacher J. P., Courtois E. A., Gaucher P., Lima J. D., Nunes P. M. S., De Souza S. M. \& Rodrigues M. T. 2019b. - Phenotypic and life-history diversification in Amazonian frogs despite past introgressions. Molecular phylogenetics and evolution 130: 169180. https://doi.org/10.1016/j.ympev.2018.09.010

Frost D. R. 2018. - Amphibian Species of the World: an Online Reference. Version 6.0 (Date of access). American Museum of Natural History, New York, USA. Electronic Database accessible at http://research.amnh.org/herpetology/amphibia/index.html

GaIGE H. T. 1926. - A new frog from British Guiana. Occasional Papers of the Museum of Zoology, University of Michigan 176: $1-3$.

GAUCher P. \& De MASSARY J.-C. 2005a. - Haute Wanapi. Étude de la faune, in GASC J. P. (coord.). Le faciès savane-roche des inselberg et sa participation à la biodiversité des écosystèmes guyanais. Rapport ECOFOR: 205-213.

Gaucher P. \& De Massary J.-C. 2005b. - Haut Marouini. Étude de la faune, in GASC J. P. (Coord.). Le faciès savane-roche des inselberg et sa participation à la biodiversité des écosystèmes guyanais. Rapport ECOFOR: 259-264.

Hammond D. S. 2005. - Tropical forests of the Guiana Shield: ancient forests in a modern world. Cambridge (MA): CABI publishing, 528 p. https://doi.org/10.1079/9780851995366.0000

Jungfer K.-H., Faivovich J., Padial J. M., Castroviejo-Fisher S., Lyra M. L., VON M. Berneck B., Iglesias P. P., KOK P. J. R., Macculloch R. D., Rodrigues M. T., Verdade V. K., Torres-Gastello C. P., Chaparro J. C., Valdujo P. H., Reichle S., Moravec J., Gvozdik V., Gagliardi-Urrutia G., Ernst R., De La Riva I., Means D. B., Lima A. P., Señaris J. C., WHEELER W. C. \& HADDAD C. F. B. 2013. — Systematics of spiny-backed treefrogs (Hylidae: Osteocephalus): an Amazonian puzzle. Zoologica Scripta. Stockholm, 42: 351-380. https://doi. org/10.1111/zsc. 12015

Kok P. J. R., Dezfoulian R., Means D. B., Fouguet A. \& BarrioAmoros C. L. 2018. - Amended diagnosis and new description of Pristimantis marmoratus (Boulenger, 1900) (Amphibia: Craugastoridae), with description of its advertisement call and notes on its breeding ecology and phylogenetic relationships. European Journal of Taxonomy 397: 1-30. https://doi.org/10.5852/ ejt.2018.397

Lescure J. \& Marty C. 2000. - Atlas des amphibiens de Guyane. Muséum national d'Histoire naturelle, Paris, 392 p. (Patrimoines naturels; 45).

Naka L. N., Bechtoldt C. L., Henriques L. M. P. \& BRumfield R. T. 2012. - The role of physical barriers in the location of avian suture zones in the Guiana Shield, northern Amazonia. The American Naturalist 179 (4): E115-E132. https://www.jstor. org/stable/10.1086/664627

Touroult J., Pollet M. \& Pascal O. 2018. - Overview of Mitaraka survey: research frame, study site and field protocols, in Touroult J.(ed.), “Our Planet Reviewed” 2015 large-scale biotic survey in Mitaraka, French Guiana. Zoosystema 40 (13): 327-365. https://doi.org/10.5252/zoosystema2018v40a13. http:// zoosystema.com/40/13

Uicn France, Mnhn, Gepog, Kwata, Biotope, Hydreco \& OsL. 2017. — La Liste rouge des espèces menacées en France Chapitres de la Faune vertébrée de Guyane. Paris, France. 35 p., https://inpn.mnhn.fr/docs/LR_FCE/181231_Rapport_evaluation_LR_Mamm_Guyane-VF2.pdf

VACHER J.-P., KoK P. J. R., RODRigUeS M. T., Dias LiMA J., LORENzini A., Martinez Q., Fallet M., Courtois E. A., Blanc M., Gaucher P., Dewynter M., Jairam R., Ouboter P., Thebaud C. \& FouQUeT A. 2017. - Cryptic diversity in Amazonian frogs: integrative taxonomy of the genus Anomaloglossus (Amphibia: Anura: Aromobatidae) reveals a unique case of diversification within the Guiana Shield. Molecular Phylogenetics and Evolution 112: 158-173. https://doi.org/10.1016/j.ympev.2017.04.017 